\title{
SOME DYNAMIC ASPECTS IN THE DESIGN OF MARINE STRUCTURES ON THE GREAT LAKES
}

Luther A. Mueller, (Deceased), Chicazo District Office, Corps of Engineers Herman A. Knutson, Great Lakes Division Office, Corps of Engineers A. Arthur Koch, Pan American Consultants, Chlcago, Illinois

\section{IN TRODUCTION}

An investigation of the failures of a number of narine structures located in the southern portion of Lake Michigan has shown that forces nust have existed at the time of failure of a type and of a magnitude whose significance to adequate design had not always been fully realized. The purpose of this paper is to indicate the probable nature of these forces and in one or two instances to estim te their magnitudes.

\section{NATURE OF FORCES}

The forces believed to be critical in the structures studied are the following:

1. Up-pressures acting on component elements of composite type breakwaters. These forces appear to be the reault of hydrostatics as well as of the dynamic action of waves.

2. Horizontal dynamic pressures of high intensity resulting from breaking waves which act in the vicinity of the mean storm water surface.

3. Vibration resonance phenomena in certain structures which occur when the netural period of the structural svetem and sustained storm wave action coincide.

\section{TYPES OF FAILURE}

Rubblemound breakwaters. Repair and maintenance records for rubblomound in the Chicago area indicate that this type of structure is subjected to disintegrating forces acting more or less continuously. The zone of marked destructive influence extends downward to approximately 12 feet below the mean lake level. The average annual lose of rock is often nearly as great for periods of little storm activity as for periods which included severe storms. Frequently the loss of stone is of the same order of magnitude for rubblemounds whose orientation and exposure would prevent direct storm attack a for breakwaters that are aligned and exposed so as to insure more direct storm wave action. Al though no measurement are available it is believed that the disintegration is caused by long continued action of up-pressures induced by direct as well as reflected waves.

Sheet piling retaining walls. Two instances of failure of sheet piling walls so located as to expose them to frequent and sustained storm wave action shows the decided possibility of the existence of action of 


\section{COASTAL ENGINEERING}

resonance between the applied period of the atorm waves and of the natural period of the structural systems. In both cases the atructures failed diring storms of moderate intensity but of sustained duration ( 30 to 42 hours). The structural and corresponding storm wave periods were in the range of 6.5 to 7.0 second 8 .

Walls on composite breakwaters. The displacement of very large cap stones on rubblemound breakwaters and the rupture of heavy concrete foot blocks on timber crib structures during intense storms supports the contention that severe dynamic forces must have occurred in the vicinity of the mean storm water aurface. Evidence also indicated that dynamic wave action took place not only on sloping structures in relatively shallow water but occurred 2 well on breakwaters with vertical faces in water as deep as 35 feet. The concurrent action of up-pressures and of horizontal wave forces was evident in the cases investigated.

Cellular breakwaters. There has been only one case of complete failure of a cellular ateel sheet plling breakwater in the lower Lake Michigan region (1949). These cello were sand filled with a water depth of 25 feet. An analyais of the causes of failure showed that wave forces of high intensity probably existed near the mean water surface and that vibration and wave overtopfing caused 1088 of the and fill. The resulting reduction of friction between the fill and the walls of the cells allowed slippage to occur along the vertical interlocks of the piling so that the structure was caused to fail by tipping. The cossibility of this form of fallure of sand filled cellular breakwaters had been pointed out by Dr. Karl Terzaghi in 1945.

\section{DYNAMIC WAVE FORCE}

The large forces exerted on breakwaters by storm waves in Lake Michigan, as is borne out by the destructive effects noted at or near the mean storm water surface, precludes the use of any design criteria which does not include the dynamic effects of breaking waves. Formulas such 28 those developed by Sainflou find application in the Chicago area only in those rare instances in deepest water where waves do not readily break. Perhaps this is due to the fact that the relatively ohort period waves representative of the Great Lakes break more frequently in moderately deop water than do the longer period waves of the oceans.

The following linear relationahip between wave height and dynamic wave pressure was developed from the hydraulic bore equation, as modified by velocity coefficients evaluated from the solitarr wave profile curves of Munk, and the dynamic resisting force of a stationary flat plate.

$$
p_{\max }=133.6 \mathrm{H} \text { (1bs./8q. ft., in fresh water) }
$$

Concerning factual information on maximum dynamic wave pressurea, the measurements made by Capt. D. D. Gaillard, U.S.A., represents the only observations of prototype forces to be expected in the Great Lakes. A comparison of those observations and the pressures predicted by equation (1) is shown in Figure (1). 
SOME DYNAMIC ASPECTS IN THE DESIGN OF MARINE STRUCTURES ON THE GREAT LAKES

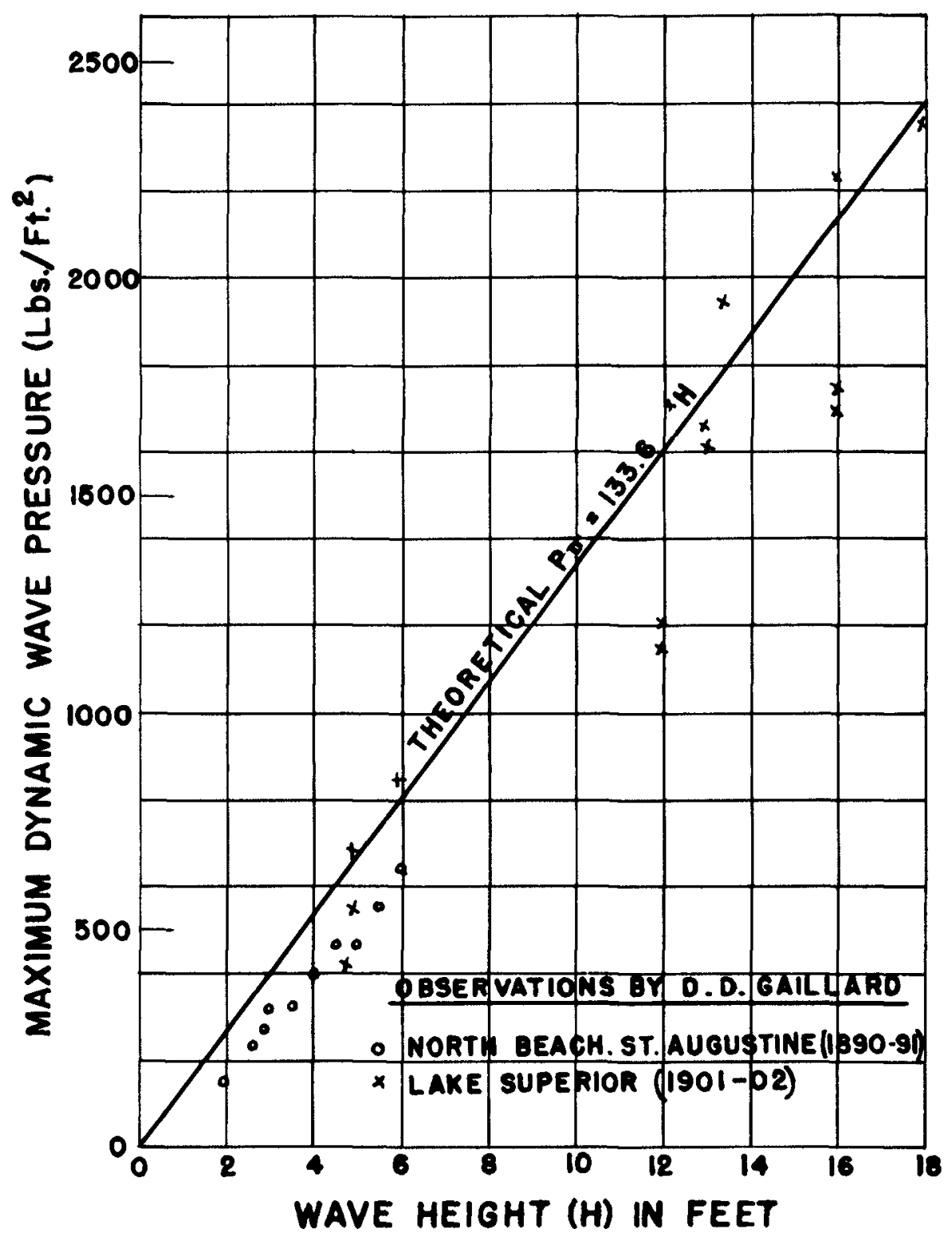

Fig. 1. Relationship between wave heights and maximum dynamic wave pressures. 


\section{COASTAL ENGINEERING}

\section{EXA'IPLES OF FAILURE}

Gary Breakwater. As an example of the failure of a composite breakwater the United States Steel Company's atructure at Gary, Indiana (Figure 2) will be analyzed so as to eatimate the forces which had acted. This breakwater, see Figure 3 , is a rock filled timber crib that had been capped with concrete. As a result of a severe storm on 25 and 26 November 1950 a 200 foot long section ( 2 crib lengths) of concrete cap slid laterally a distance of 3 to 4 feet. (Figure 5 ).

An anemometer located on the U. S. Steel unloading bridge at Gary, adjacent to the breakwater, recorded wind from NIW averaging $36 \mathrm{~m} \cdot \mathrm{p} \cdot \mathrm{h}$. for 18 consecutive hours. During this period wave heights of 14 feet were eatimated by attendants at the Chicago Water Intake Crib (Dunne). Recording wind gages at the South Side Filtration Plant and at the Navy Pier, Chicago, showed wind velocities similar to those at Gary.

Using wind duration-velocity and wave height curves it was eatimated that the deep water waves were 17 feet in height with a 7.2 second period. The corresponding wave height at Gary breakwater (water depth of 35 feet) was computed to be 13.5 feet.

The concrets cap (Figure 4) weighs $25,600 \mathrm{lbs}$, per lineal $\mathrm{ft}$. On the bagis of a coefficient of friction $=0.6$ (probably higher at failure), the force required to diaplace cap $=0.6 \times 25,600=15,630 \mathrm{lbs}$, per lineal $\mathrm{ft}$. Additional resiatance to displacement was provided by $1 \frac{1}{8}$ " drift bolts apaced at $3^{\prime}-0^{\prime \prime}$ centers in both walls. A conservative value for the resiatance of drift bolts would be $1000 \mathrm{lbs}$. per lineal ft. based on the fact that they were probably atreesed to the yield point before displacement of the cap could have occurred. Therefore, the total resiatance to sliding was 16,630 lbs. per lineal $\mathrm{ft}$.

Depending upon the magnitude and diatribution of uplift that acted, it appears that the wave force acting on the Gary breakwater to cause failure had a peak intensitv of from $1440 \mathrm{lbs}$. per sq. $\mathrm{ft}$. to $2500 \mathrm{lbs}$. per square foot (baeed on a horizontal force preseure distribution curve in which the average intensity is $50 \%$ to $67 \%$ of peak intensity).

Cellular Breakwater, Indiana Farbor. During the same storm of November 1950, a sand filled ateel sheet piling cellular breakwater failed by tipping at Indiana Harbor (located Ni of Gary, Figure 2). In this instance the maximum dmanic pressure to cause failure for a computed wave height at the breakwater (depth $=25 \mathrm{ft}$.) of 12 feet was approximately 1800 lbs. per sq. ft.

Other Cases. Captain Galllard has reported similar earlier failures of marine structures in the Great Lakes. A notable example occurred at the north breakwater, Buffalo Harbor, New York, during the atorm of 12 September 1900. The breakwater was of the crib type with capatones 5 feet high, and bases $7 \mathrm{ft}$. $x 8 \mathrm{ft}$. Each block weighed 27,800 lbs. A rough computation indicates that in the vicinity of the mean atorm water surface the average wave force required to diaplace the stones must have been in the range 600-1000 lbs. per square foot with corresponding peak preseures 
SOME DYNAMIC ASPECTS IN THE DESIGN OF MARINE STRUCTURES ON THE GREAT LAKES
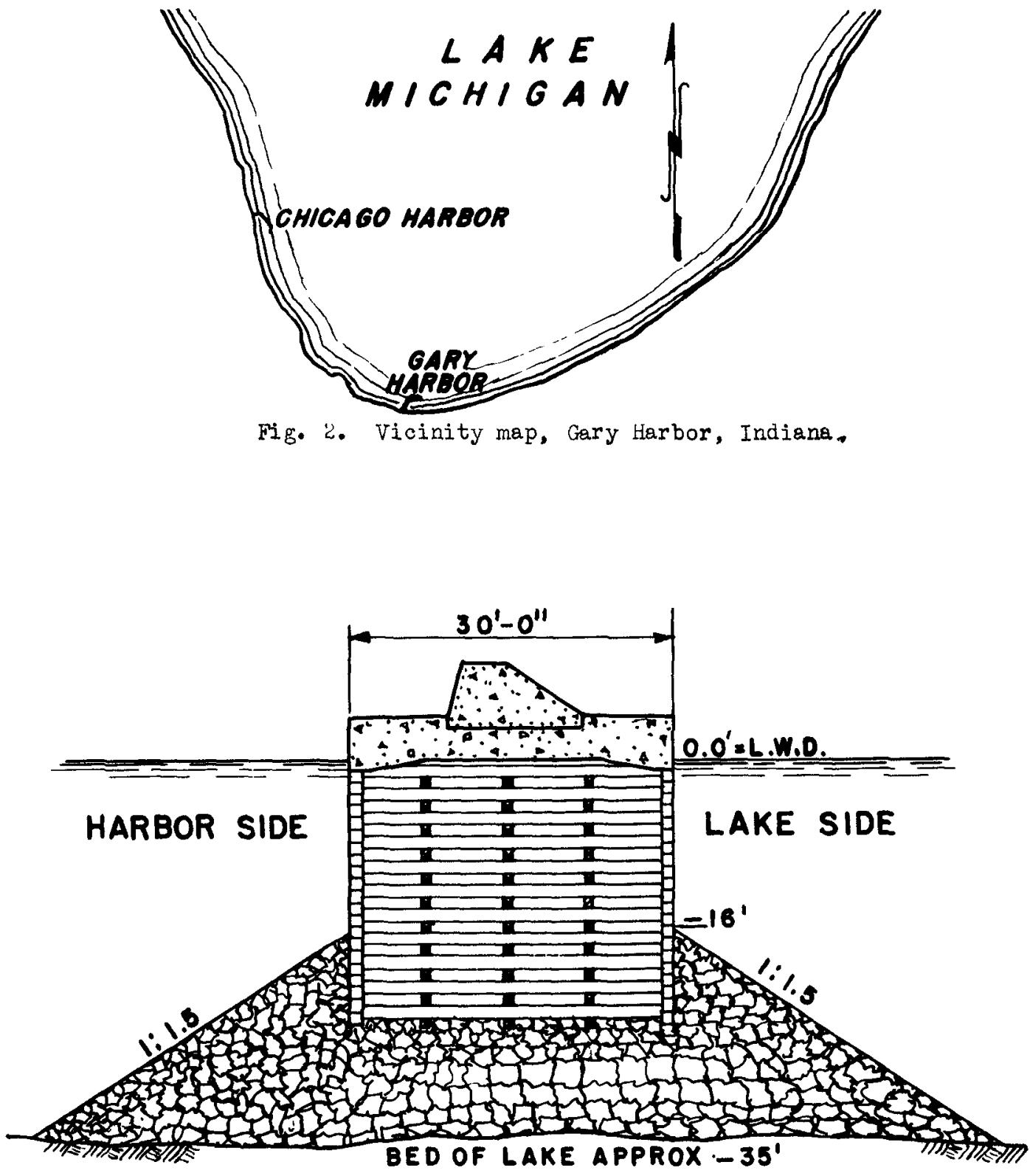

Fig. 3. Cross-section of Gary breakwater 
COASTAL ENGINEERING

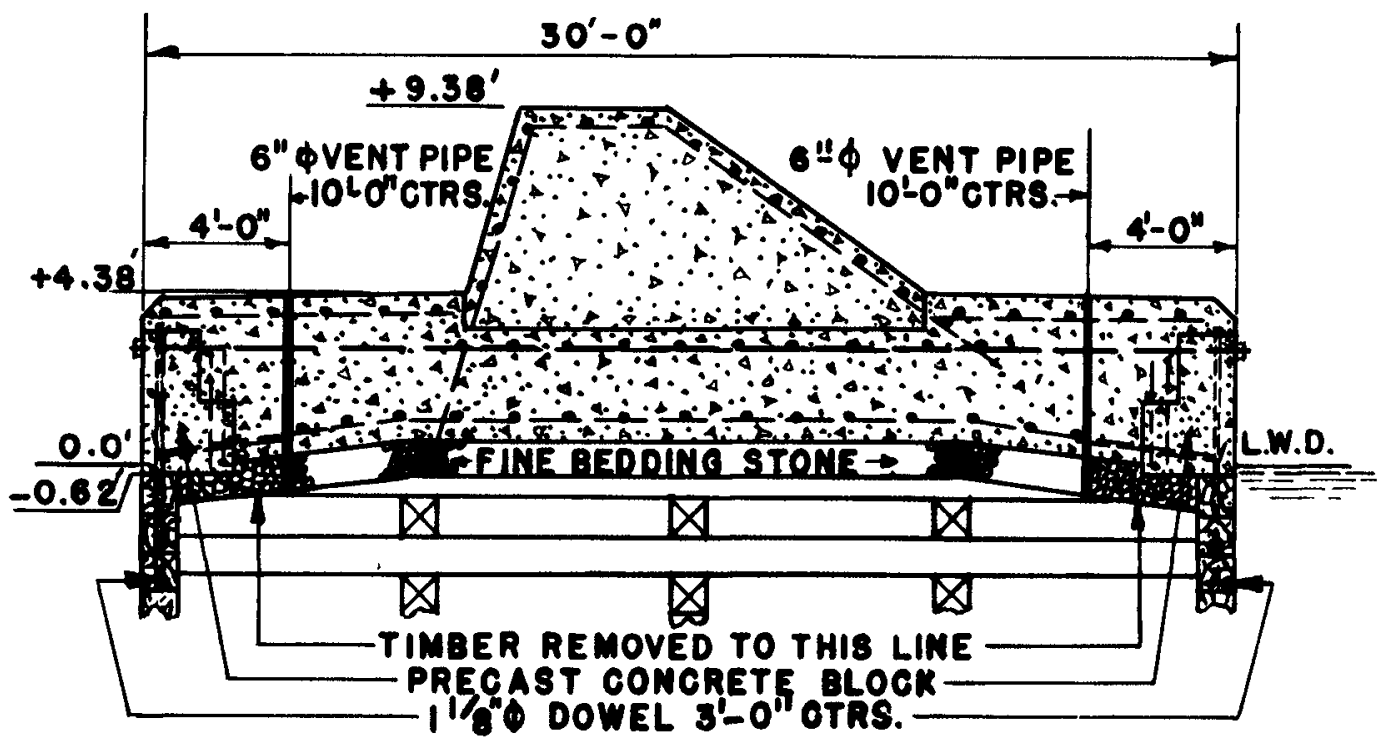

Fig. 4. Details of cap stone construotion.

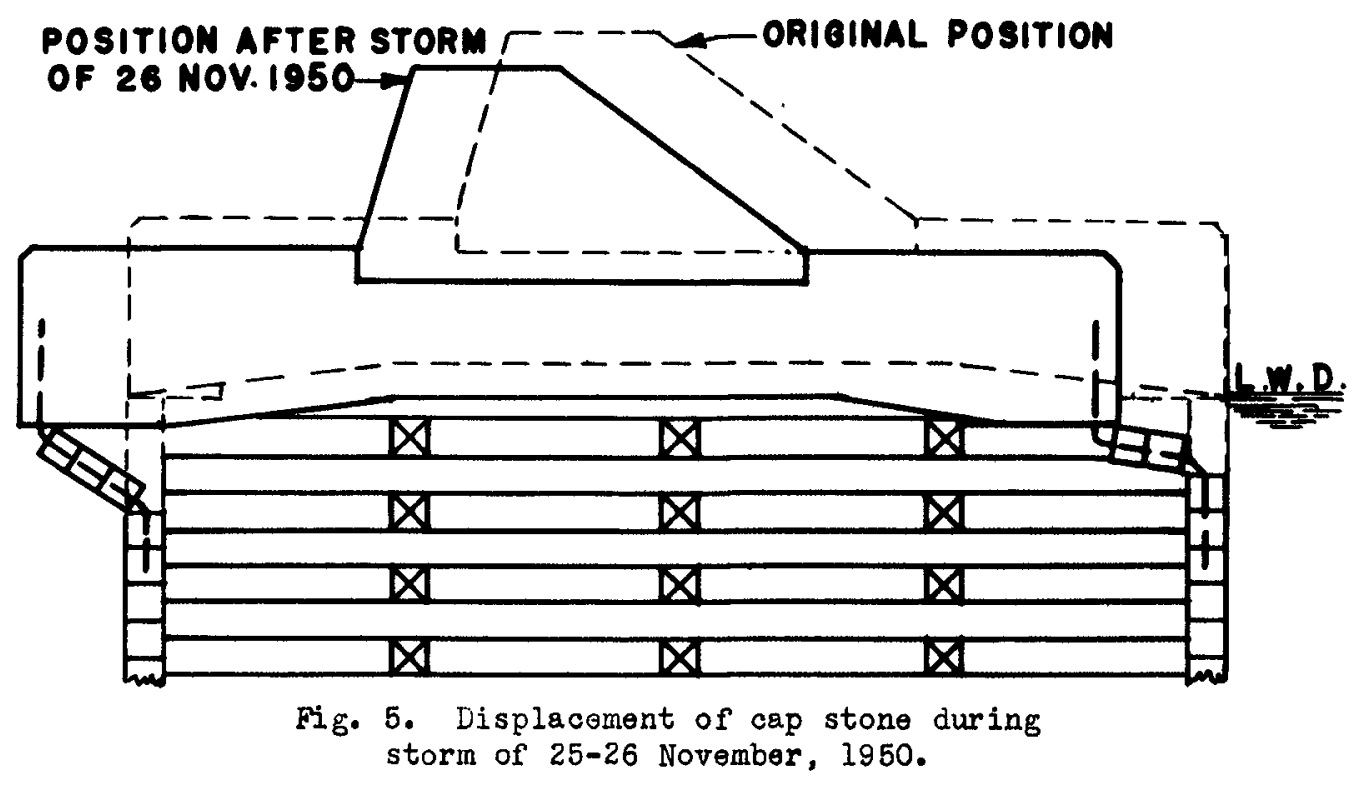


SOME DYNAMIC ASPECTS IN THE DESIGN OF MARINE STRUCTURES

\section{ON THE GREAT LAKES}

of 1000 to 1900 lbs. per square foot, depending upon the uplift assumed acting concurrently.

\section{CONCLUSIONS}

The foregoing description and analyses of fatluree of marine structures in the Great Lakes indicates the not infrequent occurrence of heavy wave pressures (and concurrent uplifts) that can only be adequately accounted for as resulting from forces set up by waves breaiking in relatively deep water. Studies of this type indicate the desirability of further study of the nature and measurements of the magnitude of these forces so ae to be able to determine adequate design criteria.

\section{REFERENCES}

Terzagh1, K (1945). Cellular cofferdams; Trang. A.S.C.E., vol. 110.

Munk, W. H. (1949). The solitary wave theory and its application to eurf problems; Ann. New York Acad. Sc1., vol. 51, art. 3.

Gaillard, D. D., Capt. (1901). Wave action; Fort Belvoir, Va.

Wileon, B. W. (1953). Oscillations of the sea and the phenomenon of range; The Dock and Harbour Authority, vol. 34, nos. 392-396. 